International Research Journal of Management, IT \& Social Sciences
Available online at https://sloap.org/journals/index.php/irjmis/
Vol. 7 No. 2, March 2020, pages: 44-49
ISSN: 2395-7492
https://doi.org/10.21744/irjmis.v7n2.871

\title{
Education model of principles on the relationship (PRIOR) for native youth organizations of sekaa teruna teruni improving reproductive health behavior of teenagers in Denpasar city
}

Article history:

Submitted: 27 January 2020

Revised: 18 February 2020

Accepted: 09 March 2020

Keywords:

behavior;

education;

health reproductive;

principles on the relationship

(PRIOR);

teenagers;

\begin{abstract}
Reproductive health problems in teenagers become an important issue in Indonesia. A program has been done in national scale, but that's program have many obstacles, the service time is during working hours, so there are difficult to access, they also have limited resources, Only $12 \%$ of teenagers know about that's a program and only $2 \%$ access that services. This is a community trial, involve 241 teenagers. The results showed that there is a significant effect in knowledge 95\% CI (14,627-21,952), attitudes 95\% CI $(6,000-9,001)$ and practices $95 \%$ CI (0.380-2.46), while in negotiation skills there is no effect $(\mathrm{P}>0.05)$. Conclusion: The educational intervention model of PRIOR has been proven to improve knowledge, attitudes, and practices. Research suggestions: It is necessary to provide a negotiation strategy topic in an education program for reproductive health to improve the achievement of knowledge, attitudes, and practices into the negotiation skills.
\end{abstract}

International research journal of management, IT and social sciences (C) 2020. This is an open access article under the CC BY-NC-ND license (https://creativecommons.org/licenses/by-nc-nd/4.0/).

Corresponding author:

Moh Fairuz Abadi,

STIKes Wira Medika, Denpasar, Indonesia.

Email address: zabadnews@gmail.com

STIKes Wira Medika, Denpasar, Indonesia

Udayana University, Denpasar, Indonesia 


\section{Introduction}

Reproductive health problems and diseases caused by infection through sexual contact become important issues in Indonesia. In 2018 640,000 people were living with HIV and there were 46,000 new infections, the incidence rate per 1000 population was 0.17 , the prevalence rate in the $15-49$ age group was $0.4 \%$. Population mortality due to AIDS since 2010 has increased by $60 \%$. Only $11.37 \%$ of the total population aged 15-24 years have good knowledge about preventing HIV transmission through sexual contact (UNAIDS, 2018). Bali is the 5th province with the highest number of AIDS cases nationally (Ministry of Health, 2017), the highest proportion of HIV/AIDS infections in the Province of Bali is due to sexual behavior (Departement of Health Bali Province, 2016). Education about reproductive health in adolescents in Bali tends to get permissive responses, the substance of reproductive health promotion is seen to contain controversy among the people because there are any differences in perspective and community beliefs. So that it inhibits the promotion of adolescent reproductive health (Foreit \& Foreit, 2003; Kamiya, 2011; Keygnaert et al., 2014).

Bali has a local culture called the Sekaa Teruna Teruna group. Sekaa Teruna Teruni membership is mandatory for Balinese youth. Sekaa Teruna Teruni members are bound to the local subjective norm, teenagers in Sekaa Teruna Teruni group are conditioned in social pressure from people around them (significant others). The education model of PRIOR is a reproductive health education service for teenagers in Sekaa Teruna Teruni youth group. The purpose of the education model of PRIOR are to improve reproductive health behaviors in knowledge, attitudes, practices and negotiation skills of teenagers positive behaviors (Plant \& Foster, 1991; Hornby \& Collins, 1981; Chacko et al., 1989).

Vygotsky's theory explained that's behaviors human development are consists of the two-way learning procedure, the first is based on the biological maturity process and the second is come on learning culture. Vygotsky emphasizes that the social, historical, and cultural determinant in social interaction were lead the development in teenagers to respond to the problem around them (Masutov, 2015).

Theory of Reasoned Action (TRA) by Fishbein and Ajzen explained that's a logical consideration based on norm, belief, attitude, intention, and the social pressure, are the principal concept to forming the behaviors (Francis et al., 2004), in the other theory Kurt Lewin explained that's the imbalance between the driving force and restraining force at individual behaviors can reconstruct the behavior. Driving forces such as the intention, perception, ability, etc. are a factor to driving someone to something, and then the restraining force such as the risk, the fear, social punishment, etc. become the hold back factor to do something, Based in that's theory above are assumed that's the interventions by educating teenagers at the cultural and social interaction through the native group can improve their reproductive health behaviors (Card, 1999; Psacharopoulos, 1994).

\section{Materials and Methods}

This is a community trials study with a randomized pretest-posttest control group design. The population is Sekaa Teruna Teruni members in the City of Denpasar, Bali Province. The sampling procedure is done by randomizing multistage, the respondents were 241 teenagers. Model education of the PRIOR instrument was developed by involving the teachers from the educational qualifications of Counseling. The interventions are consist of five meetings topics and then followed by filling in the activity calendar in 14 days. The topics are adolescent growth and puberty, healthy eating, the risk of reproductive health and abortion (Aryani et al., 2017). The questionnaire was adapted from the PKPR program established by the Ministry of Health. All questionnaires have been tested for validity and reliability for the equivalent trial group. The data collection process includes filling the pre-test questionnaires, interventions education of PRIOR to and then the sessions of post-test questionnaires. The data were analyzed statistically using SPSS.

\section{Results and Discussions}

Table 1

Characteristics between at treatment and control groups in sociodemography

\begin{tabular}{lll}
\hline Characteristic & $\begin{array}{l}\text { Intervention groups } \\
\mathrm{n}(\%)\end{array}$ & $\begin{array}{l}\text { Control groups } \\
\mathrm{n}(\%)\end{array}$ \\
\hline
\end{tabular}

Location

Abadi, M. F., \& Duarsa, D. P. (2020). The Education model of principles on the relationship (PRIOR) for native youth organizations of sekaa teruna teruni improving reproductive health behavior of teenagers in Denpasar city. International Research Journal of Management, IT and Social Sciences, 7(2), 44-49. https://doi.org/10.21744/irjmis.v7n2.871 


\begin{tabular}{|c|c|c|c|}
\hline Sub Urban & $76(57.6)$ & $46(42.2)$ & 0.97 \\
\hline Urban & $56(42.4)$ & $63(57.7)$ & \\
\hline \multicolumn{4}{|l|}{ Gender } \\
\hline Male & $76(57.6)$ & $71(65.1)$ & 0.23 \\
\hline Female & $44(42.4)$ & 38 (34.9) & \\
\hline \multicolumn{4}{|l|}{ Age } \\
\hline $12-15$ & $9(6.8)$ & $4(3.7)$ & 0.21 \\
\hline $16-19$ & $79(59.8)$ & $58(53.2)$ & \\
\hline $20+$ & $44(33.3)$ & $47(43.1)$ & \\
\hline \multicolumn{4}{|l|}{ Residence } \\
\hline Live with parent & $131(99.2)$ & $106(97.2)$ & 0.22 \\
\hline Do no live with parent & $1(0.8)$ & $1(2.8)$ & \\
\hline \multicolumn{4}{|l|}{ Activity } \\
\hline School & $97(73.5)$ & $75(68.8)$ & $0, .42$ \\
\hline Work & $35(26.5)$ & $34(31.2)$ & \\
\hline \multicolumn{4}{|l|}{$\begin{array}{l}\text { Information on health } \\
\text { reproduction }\end{array}$} \\
\hline Exposure & $108(81.8)$ & $93(85.3)$ & 0.46 \\
\hline Non exposure & $24(18.2)$ & $16(14.7)$ & \\
\hline
\end{tabular}

Table 2

Proportions of knowledge, attitudes and practices and skills of negotiation in the intervention groups

\begin{tabular}{|c|c|c|c|c|c|}
\hline \multirow[t]{2}{*}{ Variable } & \multicolumn{2}{|c|}{ Pre test } & \multicolumn{2}{|c|}{ Post test } & \multirow[t]{2}{*}{$\mathrm{p}$} \\
\hline & $\mathrm{n}$ & $\%$ & $\mathrm{n}$ & $\%$ & \\
\hline \multicolumn{6}{|l|}{ Knowledge } \\
\hline Excellent & 22 & 16.7 & 8866.7 & 66.7 & \multirow[t]{6}{*}{$0.00^{*}$} \\
\hline Good & 56 & 42.4 & 1712.9 & 12.9 & \\
\hline Average & 19 & 14.4 & 75.3 & 5.3 & \\
\hline Fair & 24 & 18.2 & 139.8 & 9.8 & \\
\hline Poor & 11 & 8.3 & 75.3 & 5.3 & \\
\hline Total & 132 & 100.0 & 132 & 100.0 & \\
\hline \multicolumn{6}{|l|}{ Attitude } \\
\hline Excellent & 34 & 25.76 & 69 & 52.27 & \multirow[t]{6}{*}{$0.00^{*}$} \\
\hline Good & 47 & 35.61 & 35 & 26.52 & \\
\hline Average & 39 & 29.55 & 23 & 17.42 & \\
\hline Fair & 10 & 7.58 & 4 & 3.03 & \\
\hline Poor & 2 & 1.52 & 1 & 0.76 & \\
\hline Total & 132 & 100.0 & 132 & 100.0 & \\
\hline \multicolumn{6}{|l|}{ Practice } \\
\hline Excellent & 16 & 12.12 & 20 & 15.15 & \multirow[t]{6}{*}{$0.03 *$} \\
\hline Good & 20 & 15.15 & 26 & 19.7 & \\
\hline Average & 47 & 35.61 & 54 & 40.91 & \\
\hline Fair & 14 & 10.61 & 15 & 11.36 & \\
\hline Poor & 35 & 26.52 & 17 & 12.88 & \\
\hline Total & 132 & 100.0 & 132 & 100.0 & \\
\hline \multicolumn{6}{|c|}{ Skills of negotiation } \\
\hline Excellent & 2 & 1.52 & 1 & 0.76 & \multirow[t]{6}{*}{0.28} \\
\hline Good & 30 & 22.73 & 30 & 22.73 & \\
\hline Average & 71 & 53.79 & 57 & 43.18 & \\
\hline Fair & 25 & 18.94 & 41 & 31.06 & \\
\hline Poor & 4 & 3.03 & 3 & 2.27 & \\
\hline Total & 132 & 100.0 & 132 & 100.0 & \\
\hline
\end{tabular}


Table 2. showed that's there are significant differences in the proportions of knowledge, attitudes, and practices, (p $<0.05)$, whereas in negotiation skills known to be no significant difference.

Table 3

Comparison of mean rank in knowledge, attitudes, practices, and skills of negotiation before and after intervention in intervention and control groups

\begin{tabular}{|c|c|c|c|c|c|c|c|}
\hline \multirow[t]{2}{*}{ Variable } & \multicolumn{2}{|c|}{ Intervention } & \multicolumn{2}{|r|}{ Control } & \multirow[t]{2}{*}{$\mathrm{p}$} & \multicolumn{2}{|c|}{$95 \% \mathrm{CI}$} \\
\hline & $\mathrm{n}$ & Mean Rank & $\mathrm{n}$ & Mean Rank & & Min & Max \\
\hline \multicolumn{8}{|l|}{ Knowledge } \\
\hline Pre test & 132 & 117.03 & 109 & 125.8 & 0.33 & -7.31 & 2.43 \\
\hline Post test & 132 & 149.35 & 109 & 86.5 & 0.00 & 14,627 & 21,952 \\
\hline Post test-Pre test & 132 & 147.17 & 109 & 89.31 & 0.00 & 14.63 & 26.82 \\
\hline \multicolumn{8}{|l|}{ Attitude } \\
\hline Pre test & 132 & 138.03 & 109 & 100.83 & 0.00 & 1.99 & 6.99 \\
\hline Post test & 132 & 150.62 & 109 & 85.12 & 0.00 & 6,000 & 9,001 \\
\hline Post test-Pre test & 132 & 137.67 & 109 & 100.81 & 0.00 & 1.62 & 4.15 \\
\hline \multicolumn{8}{|l|}{ Practice } \\
\hline Pre test & 132 & 112.24 & 109 & 131.48 & 0.34 & -2.07 & -0.08 \\
\hline Post test & 132 & 132.24 & 109 & 107.39 & 0.00 & 0.380 & 2.46 \\
\hline Post test-Pre test & 132 & 133.05 & 109 & 166.41 & 0.00 & 0.78 & 2.46 \\
\hline \multicolumn{8}{|l|}{ Skills of Negotiations } \\
\hline Pre test & 132 & 120.74 & 109 & 121.31 & 0.95 & -0.13 & 0.12 \\
\hline Post test & 132 & 113.65 & 109 & 129.9 & 0.07 & -0.25 & -0.00 \\
\hline Post test-Pre test & 132 & $-0.05^{\mathrm{a}}$ & 109 & $-0.01^{\mathrm{a}}$ & $0.69^{\mathrm{b}}$ & $-0.24^{b}$ & $0.16^{\mathrm{b}}$ \\
\hline
\end{tabular}

${ }^{\mathrm{a}}=$ mean,${ }^{\mathrm{b}}==$ T test

According to the data in Table 1. It was showed that's there are no different characteristics in statistical between at treatment and control groups in sociodemography ( $p>0.05)$. the meaning that's at treatment and control group are in the equal.

According to the data in Table 2, it was found that the proportion of knowledge in the treatment group had increased. Before the intervention, the majority of the knowledge of the treatment group was in the "Good" category $(42.4 \%)$, and after the intervention, it was found that the majority of the proportion of the level of knowledge was in the "Excellent" category $(66.7 \%)$. This intervention has also increased the proportion in attitudes before interventions known that's the majority attitudes in the treatment group were in the "Good" category $(35.61 \%)$, then after the intervention, it was found that the majority of the respondents' attitudes were in the "Excellent" category (52.27\%). In the variable of practice, it's found that's this intervention increase the proportion of practice, the "Excellent" was an increase from $12.12 \%$ to $15.15 \%$, in the "Good" category also had increased from $15.15 \%$ to $19.70 \%$, and for the "average" category it increase from $35.61 \%$ to $40.91 \%$. Changes in the proportion of knowledge, attitude and practice can also be seen from the significance of the p-value between pre-test and post-test practice in the intervention group $\mathrm{p}<0.05$, whereas in the control group there was no statistically significant difference $(p>0.05)$. Meaning that the increase in the proportion of respondents regarding reproductive health behavior because of interventions is statistically significant. The effect of the intervention into the proportion of negotiation skills statistically did not affect ( $p>0.05)$. According to the data, could be seen that's there is no pattern was found on the effect of the intervention to the negotiation skills.

Table 3 showed that there were significant differences $(\mathrm{P}<0.05)$ in knowledge $95 \% \mathrm{CI}(14,627-21,952)$, in attitude $95 \%$ CI $(6,000-9,001)$ and in practice $95 \%$ CI $(0.380-2.46)$. There is no effect interventions in skills of negotiation (P> $0.05), 95 \%$ CI value (-0.25) - (- 0.00). According to Table 3. Based on p-value and 95\%CI in post-test known that's this intervention give a positive effect on knowledge, attitude and practice. Laswell Theory in Kurniawan (2018), describe that an intervention education effect for knowledge is determined by five elements of communication (Who, Say Whats, In which channel, To whom, and With what effect), based on that's a theory, its can be explained that's the effect of education model of PRIOR may follow that theory. The intervention was delivered by the youth facilitator, the material was compiled based on a study of adolescent reproductive health behaviors, furthermore, the material is

Abadi, M. F., \& Duarsa, D. P. (2020). The Education model of principles on the relationship (PRIOR) for native youth organizations of sekaa teruna teruni improving reproductive health behavior of teenagers in Denpasar city. International Research Journal of Management, IT and Social Sciences, 7(2), 44-49. https://doi.org/10.21744/irjmis.v7n2.871 
conveyed through the media of the native organization Sekka Teruna Teruni which has subjective norms and is conditioned in the monitoring of social pressure (significant others). Based on that's a description, researchers concluded that the intervention has fulfilled the five communication element so that the impact of the intervention has increased respondents' knowledge.

Based on the theory of model Probabilogical Model we can describe the attitude in adolescents are forming in two ways, Bayes's Theorem and Socratic Effect. Bayes's theorem state that persuasive communication can change the logical attitude and then the Socratic Effect said that individual belief can form by sequence, repetition, and consistency of information and the communication (Ramdhani 2008). The education model of PRIOR was stimulating the ability of teenagers to take the idea and understanding from that education, and directing them to make logical considerations in reproductive health behavior based on norm values, awareness, self-control, empathy and self-esteem, and emphasizing to the self-habituation and willingness to change (Taylor et al., 1984; Rovee \& Rovee, 1969). Based on that's description above, it can be concluded that the logical awareness about the advantages and disadvantages of doing or not do something and the consequences have an impact on changes in respondents' attitudes about the reproductive of health.

The practice of reproduction health in teenagers could be change, theory from Kurt Lewin, He explained human behavior is a balanced state between driving forces and restraining forces, furthermore, the behavior can be changed if there is an imbalance between the two forces within a person ( Kintoko Rochadi \& Chahaya, 2008). Driving forces is increased, this happens because there is a stimulus by the education model of PRIOR, that's were encourages behavior changes, on the other side the restraining forces decrease due to stimuli.

According to the data, it was explained that there is no effect on the intervention into negotiation skills. Theoretically, changing the ability of negotiation skills in adolescents is a more complex process than forming knowledge, attitudes, and practices. Based on the theory of ambivalent abstract cognition, we know that's in teenagers occur the ambivalent consideration phenomenon when they were negotiating about reproductive health behavior. On the one side, teenagers want to be free on reproductive behavior, but on the other side, they also afraid about the consequences and for losing the bounding love and support from their parents if they breaking up the rules in the norm (Soeroso, 2001). The cognition bias theory from Thomson also explained that at the negotiations there is could be a bias, because of different perceptions in teenagers and mistaken attribution (bias) in interactions, so that it could affect the expected outcome of negotiations (Tamba, 2005). The education model of PRIOR is designed for encouraging the negotiation skills by forming knowledge, attitude, and practice, but there was not consider yet about the phenomenon of ambivalent abstract cognition and the cognition bias at the negotiations.

\section{Conclusion}

Education Model of Principles on Relationship (PRIOR) has increased the knowledge, attitudes, and practices in reproductive health, these interventions also increase the proportion in the intervention group compared to controls. There is no influence on the skills of negotiating. Suggestions: It is necessary to provide a negotiation strategy topic in an education program for reproductive health to improve the achievement of knowledge, attitudes, and practices into the negotiation skills.

\section{Conflict of interest statement}

The authors declared that they have no competing interests.

\section{Statement of authorship}

The authors have a responsibility for the conception and design of the study. The authors have approved the final article.

\section{Acknowledgments}

Thanks and appreciations to Udayana University, Malang State University, Wira Medika Bali Health College, YSIC foundation for establishment of the reference, time and research fund. Thank you for Bali Provincial Health Service, Kerti Praja Foundation, GP Society, KISARA Bali NGO, PKBI Bali NGO, Spektra Surabaya NGO, D'SPRADA Bali NGO for good cooperation in this research. Thank you to the native organizations Sekaa Teruna Teruni Bali, Institutions in Sanur Village, Dauh Puri Kangin Village, Volunteers and the people in the research area for supporting us. 


\section{References}

Aryani, L. N. A., Ardjana, I. E., \& Hanati, N. (2017). Emotion and behaviour disorders towards children of maternal depression in psychiatry polyclinic at RSUP Sanglah. International Research Journal of Engineering, IT \& Scientific Research, 3(2), 139-149.

Card, D. (1999). The causal effect of education on earnings. In Handbook of labor economics (Vol. 3, pp. 1801-1863). Elsevier. https://doi.org/10.1016/S1573-4463(99)03011-4

Chacko, M. R., Mcgill, L., Johnson, T. C., Smith, P. B., \& Nenney, S. W. (1989). Vaginal douching in teenagers attending a family planning clinic. Journal of Adolescent Health Care, 10(3), 217-219. https://doi.org/10.1016/0197-0070(89)90236-2

Departement of Health Province of Bali. (2016). Profil Kesehatan Propinsi Bali Tahun 2016. Denpasar.

Foreit, J. R., \& Foreit, K. G. F. (2003). The reliability and validity of willingness to pay surveys for reproductive health pricing decisions in developing countries. Health Policy, 63(1), 37-47. https://doi.org/10.1016/S01688510(02)00039-8

Francis, J., Eccles, M. P., Johnston, M., Walker, A. E., Grimshaw, J. M., Foy, R., ... \& Bonetti, D. (2004). Constructing questionnaires based on the theory of planned behaviour: A manual for health services researchers.

Hornby, H. C., \& Collins, M. I. (1981). Teenagers in foster care: The forgotten majority. Children and Youth Services Review, 3(1-2), 7-20. https://doi.org/10.1016/0190-7409(81)90027-X

Kamiya, Y. (2011). Women's autonomy and reproductive health care utilisation: empirical evidence from Tajikistan. Health Policy, 102(2-3), 304-313. https://doi.org/10.1016/j.healthpol.2011.04.001

Keygnaert, I., Guieu, A., Ooms, G., Vettenburg, N., Temmerman, M., \& Roelens, K. (2014). Sexual and reproductive health of migrants: Does the EU care?. Health policy, 114(2-3), 215-225. https://creativecommons.org/licenses/bync-nd/3.0/

Kurniawan, D. (2018). Komunikasi Model Laswell Dan Stimulus-Organism-Response Dalam Mewujudkan Pembelajaran Menyenangkan. Jurnal Komunikasi Pendidikan, 2(1), 60-68. https://doi.org/10.32585/jkp.v2i1.65

Matusov, E. (2015). Vygotsky's theory of human development and new approaches to education.

Plant, M. A., \& Foster, J. (1991). Teenagers and alcohol: results of a Scottish national survey. Drug and alcohol dependence, 28(2), 203-210. https://doi.org/10.1016/0376-8716(91)90077-C

Psacharopoulos, G. (1994). Returns to investment in education: A global update. World development, 22(9), 13251343. https://doi.org/10.1016/0305-750X(94)90007-8

R Kintoko Rochadi, M. K. M., \& Ir Indra Chahaya, M. S. (2008). Hubungan Penyuluhan Dengan Perilaku Pencegahan Penyakit Malaria Pada Masyarakat Di Wilayah Kerja Puskesmas Lamteuba Kecamatan Seulimum Kabupaten Aceh Besar (Master's thesis).

Ramdhani, N. (2008). Pembentukan dan perubahan sikap. Yogyakarta: Fakultas Psikologi UGM.

Rovee, C. K., \& Rovee, D. T. (1969). Conjugate reinforcement of infant exploratory behavior. Journal of experimental child psychology, 8(1), 33-39. https://doi.org/10.1016/0022-0965(69)90025-3

Soeroso, S. (2016). Masalah kesehatan remaja. Sari Pediatri, 3(3), 189-97.

Tamba. (2015). Negosiasi. Makalah. Program Studi Magister Ilmu Komunikasi. Medan: Universitas Sumatra Utara.

Taylor, M. S., Locke, E. A., Lee, C., \& Gist, M. E. (1984). Type A behavior and faculty research productivity: What are the mechanisms?. Organizational Behavior and Human Performance, 34(3), 402-418. https://doi.org/10.1016/0030-5073(84)90046-1

UNAIDS. (2018). Country Report. Jakarta.

Abadi, M. F., \& Duarsa, D. P. (2020). The Education model of principles on the relationship (PRIOR) for native youth organizations of sekaa teruna teruni improving reproductive health behavior of teenagers in Denpasar city. International Research Journal of Management, IT and Social Sciences, 7(2), 44-49. https://doi.org/10.21744/irjmis.v7n2.871 